\title{
REGIONAL BUDGETS: AT THE END OF TETHER ${ }^{1}$
}

\section{A. Deryugin}

Improved parameters of the consolidated budgets balance of the subjects of the Russian Federation in July-October 2016 triggered by growing rates of budget revenues and curbing of expenditure growth will allow retaining the values of major budget indices at the 2015 level in real terms. Meanwhile, currently regions have got to the limits of their possibilities to raise wages to those categories of public employees who were indicated in May 2012 presidential decrees. Expected onward contraction of real volume of regions' revenues and expenses in 2017-2019 can lead to the incomplete implementation of decrees, further distortion on the structure of regional and local budgets' expenditures, debt problems as well as to the slowdown of economic growth rates.

\section{Revenues}

According to preliminary results of regional and local budgets execution for 10 months of 2016, revenues of the consolidated budgets of the subjects of the Russian Federation have moved up by $4.4 \%$ in comparison with the same period of last year, meanwhile by $\mathrm{H} 1$-end this growth came to barely $2.7 \%$. The number of regions' consolidated budgets whose revenues exceeded the corresponding level of last year has gone up ( 67 against 55 by H1-end), as well as the number of regions' consolidated budgets whose revenues growth rates exceeded the inflation level for 12 months (34 against 24). This is attributable to relatively good indicators of revenues growth registered in August (130.0\% on August 2015) and October (113.9\% on October 2015) (Fig. 1).

Thus, average growth rates of the consolidated budgets' revenues of the RF subjects for 10 months of 2016 have significantly come close to the level of the consumer price index for 12 months (106.1\%), which gives some hope for retaining real volume of regional revenues at the 2015 level.

Having said that, dynamic of the RF subjects' consolidated budgets' revenues continues to be volatile, which hampers to forecast the developments to 2016-end.

Higher growth rates of the consolidated budgets' revenues are attributable to increasing average growth rates of proceeds generated by the corporate income tax $(113.3 \%$ for July-August 2016 against $100.7 \%$ for $\mathrm{H} 1$ on the corresponding period of the previous year), excises (138.2\% against $130.2 \%)$, tax on

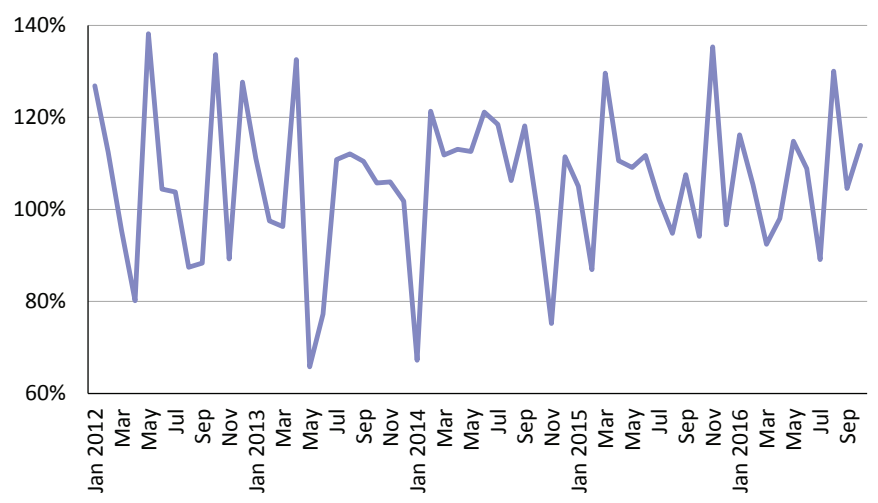

Source: calculated on data released by the Federal Treasury.

Fig. 1. Growth rates of general revenue volume of consolidated budgets of the RF subjects, to the same period of last year, \%

1 This paper was originally published in Monitoring of Russia's Economic Outlook No.18(36). 
the assets of organizations (117.2\% against $106.8 \%$ ) as well as nonrepayable receipts obtained from the budgets of other levels $(101.6 \%$ against 89.5\%).

Moreover, despite somewhat decrease of growth rates of proceeds from PIT (106.5\% for July-August 2016 against $108.4 \%$ for $\mathrm{H} 1$ ), they have remained above the inflation, which to a considerable extent was due to positive dynamics of the PIT tax base, which since the turn of the year has come out of the prolonged downward trend (Fig. 2).

Thus, average growth rates of

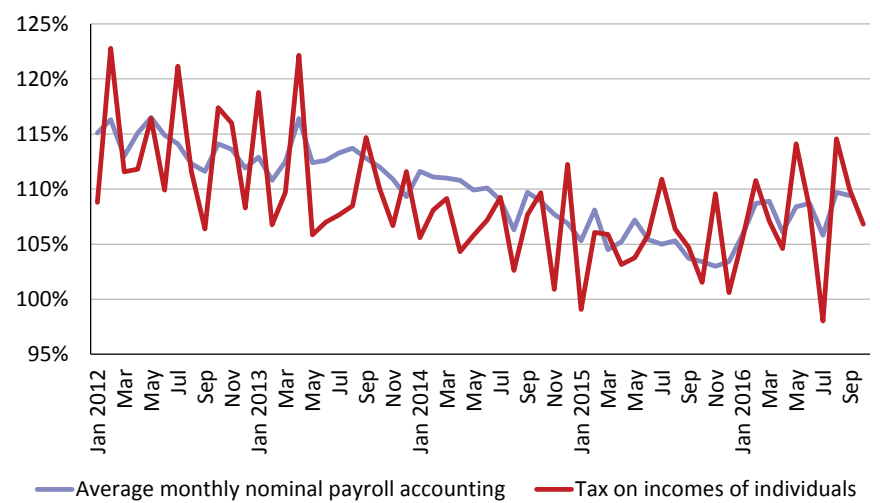

Source: calculated on data released by the Federal Treasury and Rosstat.

Fig. 2. Growth rates of the total volume of proceeds from PIT into consolidated budgets of RF subjects and average monthly nominal payroll accounting, \% against the same period of previous year tax revenues by the period-end of 10 months of the current year have come to a level exceeding the inflation rate for 12 months and the only factor, which slows down regional and local budgets' revenues are non-tax revenues (growth from the turn of the year $102.3 \%$ ) as well as non-repayable receipts from the budgets of other levels (94.3\%).

Geographically, there is a rather mixed situation: each federal okrug has regions with relatively high and low growth rates of budget incomes and the average indicators of growth rates of consolidated budgets' revenues across federal okrugs stay relatively close. If we analyze the situation from the point of view of a ratio of number of regions' consolidated budgets whose revenues grew faster than inflation to the total number of regions in the okrug, then leaders by growth rates are Far-Eastern and North-Western federal okrugs ( 67 and $55 \%$, respectively), and lagging behind North-Caucasus (14\%), Central (22\%), and South (25\%) federal okrugs.

\section{Expenditure}

By the period-end of 10 months of 2016, total growth the RF subjects' consolidated budgets' expenditures has come to $104.2 \%$ on the same period of the previous year, which is below inflation registered for 12 months. Main curbing owed to wages, which in nominal terms have remained around the last year's level (100.1\%). At the same time, by H1-end, one can note a significant growth of public and non-public social payments (114.1\% to H1 2015), which is determined by the indexation following high inflation registered in 2015.

High rates of capital investment growth posted by H1-end (149.7\% to H1 2015) have shrunk to $104.7 \%$ by 10 months-end, which attributes to their more active disbursement in $\mathrm{H} 1$, which, in its turn, was due to current phases of the electoral cycle in Russia. Consequently, further reduction of real volume of capital expenses from regional and local budgets is expected by the end of 2016.

Reduction of real expenditure volume had an impact on the implementation of May Presidential Decree No. 597 (2012), which envisages bringing salaries of a number of categories of state and municipal employees to the level of average or double average level existing in the economy. According 
to the Program of step-by-step improvement of the compensation plan in state (municipal) organizations for 2012-2018, ratio of average salary of state employees and average wage in the economy must annually grow to reach the target level. Along with that in H1 2016 compared to H1 2015, deterioration of indices of its implementation has been observed: "delay" of the target value has increased on a majority of categories: across 9 categories on the regional level, and across 7 categories on the municipal one. This fact either speaks about reaching regional potential to increase pay increase for "mentioned" categories or is purely technical consequence of growing rates of average wage in the economy (Fig. 2).

\section{Budgets balance and public debt}

Increased growth rates of budget revenues of RF subjects and decline of growth rates of expenditure registered in H2 2016 have improved general parameters of regional budgets balance. As a result, total current surplus of regions' consolidated budgets by the period-end of 10 months of 2016 has surpassed corresponding indicator for the same period of last year ( $\mathrm{Rb}$ 539.7 bn against $R b 503.0$ bn).

Improvement of parameters of regional budgets balance was bound to tell on the dynamics of regional public debt. For example, despite some growth of its nominal

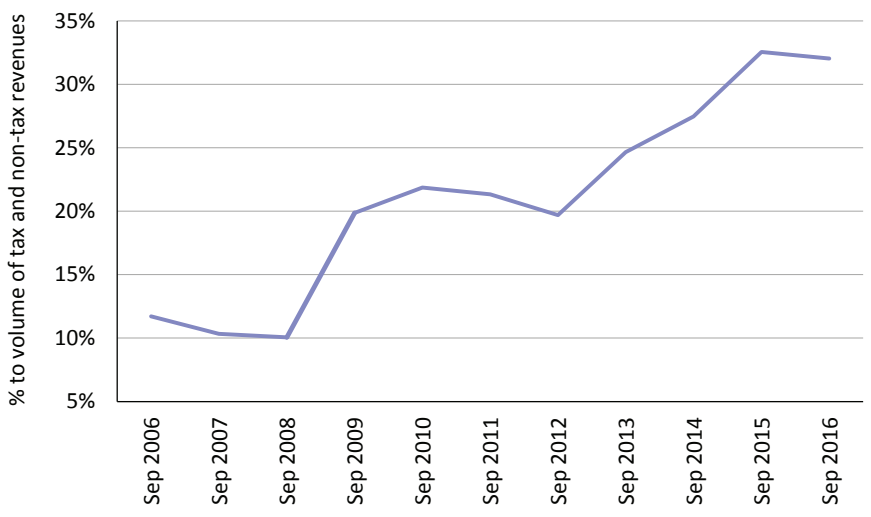

Source: calculated on data released by the Finance Ministry of Russia and the Federal Treasury.

Fig. 3. Dynamics of public debts of RF subjects, $\%$ to the volume of tax and non-tax revenues of budgets of RF subjects volume from $\mathrm{Rb} 2.17$ trillion posted in September 2015 to $\mathrm{Rb} 2.26$ trillion registered in September 2016, its ratio to the volume of tax and non-tax revenues of regional budgets has shrunk for the same period from 34.2 to $33.5 \%$, which happened for the first time during last 4 years (Fig. 3).

Despite some average contraction of tax burden of the regions, the number of RF subjects has gone up whose ratio of public debt to the volume

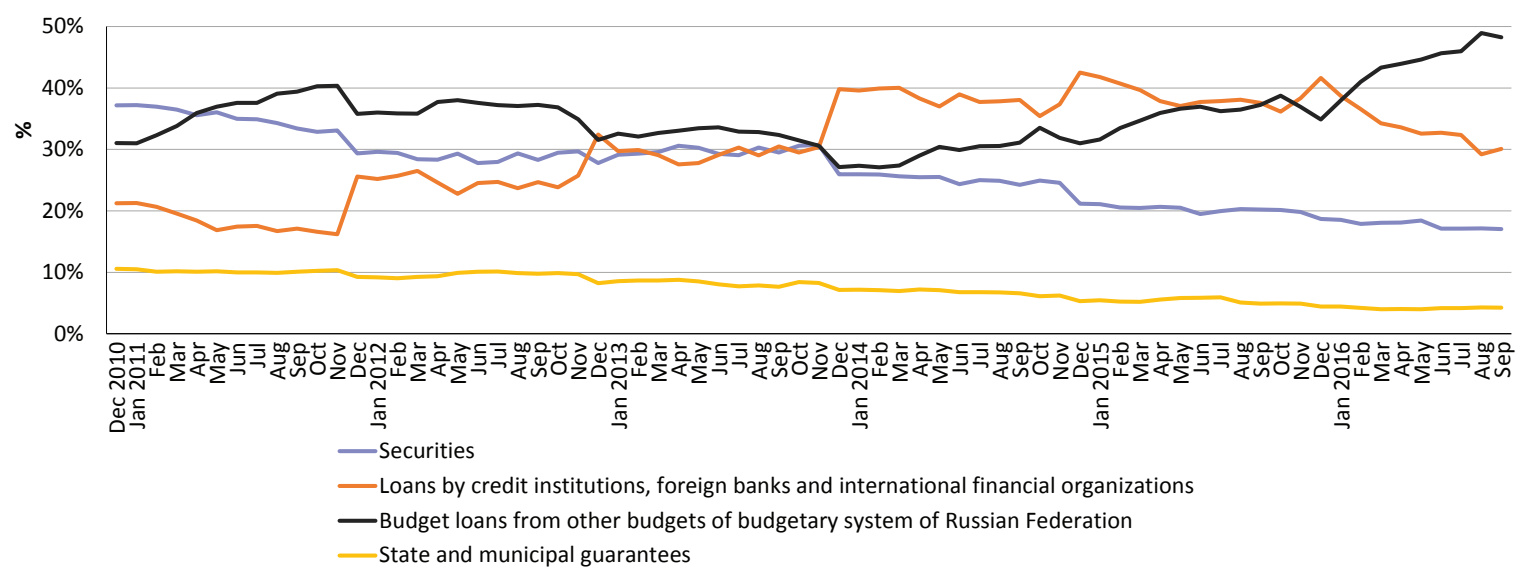

Source: calculated on data released by Finance Ministry of Russia.

Fig. 4. Structure of public debt of the subjects 
of tax and non-tax revenues of corresponding budgets exceeds $100 \%$ : from 11 posted in September 2015 to 13 registered in September 2016 and exceeding the level of $125 \%$ - from 3 to 4.

Herewith, one needs to remember that the RF Budget code sets caps on corresponding ratio for general regions at the level of $100 \%$ and for highly subsidized ones - at the level of $50 \%$. This limitation does not extend to budget credits until 1 January 2018. However, after that date, it is highly likely that over a dozen of regions will break this requirement, following which the issue of excessive regional overburdening with public debt will become a federal issue.

With respect to the structure of regional public debt, there is an ongoing upward trend in federal budget loans, which as of September 2016 came to $48.2 \%$ resulting from the growth of public budget loans, which commenced since 2014 aimed at replacing expensive commercial loans (Fig. 4).

\section{Forecast}

According to the forecast of the consolidated budgets' parameters of RF subjects indicated in materials to the draft law "On the Federal Budget for 2017 and the 2018-2019 planning period" (hereinafter - Draft law), the downward trend in real volume of budget revenue and expenditure unfolding since 2009 will be retained in the course of 2017-2019 (Fig. 5).

Contraction of real revenue volume by 2019 by $0.6 \%$ of GDP in comparison with 2016 will be due to

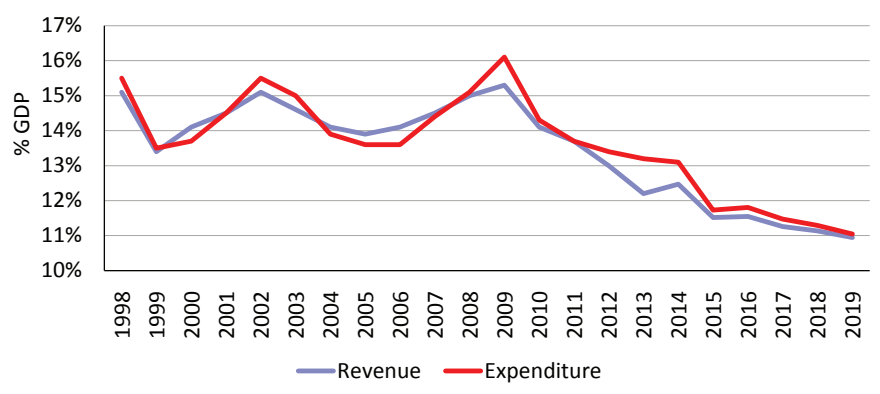

Source: 1998-2015 - calculated on data released by Federal Treasury based on budget execution reports; 2016-2019 - calculated proceeding from parameters produced in the materials for the Draft law.

Fig. 5. Dynamics of revenue and expenditure of consolidated budgets of RF subjects, \% to GDP a reduction of tax and non-tax revenue (constitutes $0.3 \%$ of GDP and linked with a transfer of $1.0 \%$ of income tax to the federal budget) and interbudgetary transfers from the federal budget (0.3\% of GDP).

Centralization of part of corporate income tax at the rate of $1.0 \%$ commencing from 2017 with further reallocation of the corresponding volume among RF subjects via the system of interbudgetary transfers will not result in the increase of real revenue volume because it will be totally offset by a contraction of actual volume of subsidies and other types of transfers from the federal budget. For example, in 2017-2019 real volume of interbudgetary transfers from the federal budget will come to $1.77,1.64$ and $1.46 \%$ of GDP, respectively. This will be below the 2016 level (1.78\% of GDP) and significantly lower average value for the period of 2005-2015 (2.4\% of GDP).

Planned contraction of real volume of the consolidated budgets' expenditure (Fig. 5) happens without a corresponding change in the delineation of powers between federation and regions. Moreover, according to the Presidential Decree of 7 May 2012 No. 597 "On Measures for the Implementation of State Social Policy," salaries of 12 categories of public sector workers should be brought to the target values by 2018. Therefore, the actual volume of regional commitments, on the contrary, should move up. Its forecast contraction, obviously, will be owing to exclusively budgetary 
caps: reduction of real volume of the consolidated budgets revenue volume of RF subjects as well as decrease of the deficit due to tighter restrictions of the budget law. (Reduction of the deficit volume limit has been planned from 15 to $10 \%$ of the approved total annual volume of budget revenue of RF subjects minus approved volume of non-repayable transfers).

Consequently, financial outlook of the regions will be deteriorating, which will result in further distortion of structure of regional budgets expenditure.

According to calculations made by RANEPA's experts based on the data released by the Finance Ministry and Rosstat, in the wake of contraction real volume of expenditure of consolidated budgets of RF subjects (minus Republic of Crimea and the city of Sebastopol), the spending on gross payroll of "mentioned" categories went up from 1.69\% of GDP in 2012 to $1.7 \%$ of GDP in 2015 and is expected to be at the level of 1.84\% of GDP in 2016. Along with this, there is a reduction of the total number of "indicated" categories of the public sector workers (by 5.1\% for the period since 2013 up to mid-2016). Despite this fact, the share of budget spending on gross payroll has moved up from 28.5 to $32.6 \%$ of the total volume of expenditure of regional consolidated budgets. Meanwhile, the share of budget investment has fallen from 13.4 to $10.1 \%$. Forecast continuation of these trends creates preconditions for the slowdown of economic growth.

Possibilities for replacing commercial loans with budget ones in 2017-2019 will also be restricted. Draft law envisages decrease of the volume of the budget loans origination in 2017-2018 threefold compared to 2016 - from $\mathrm{Rb} 310 \mathrm{bn}$ to $\mathrm{Rb} 100 \mathrm{bn}$ and to $\mathrm{Rb} 50 \mathrm{bn}$ by 2019 . Thus, there will appear preconditions for building up expensive commercial debt, which will also reduce investment potential of regions. 